\title{
実在中低層鋼構造骨組の耐震性能に関する研究 A CONSIDERATION ON EARTHQUAKE RESISTANT ABILITY OF EXISTING LOW OR MIDDLE RISE STEEL STRUCTURES
}

\author{
前田 憲太郎*1, 增 田 浩 志*2, 田中淳夫*3 \\ Kentarou MAEDA, Hiroshi MASUDA and Atsuo TANAKA
}

\begin{abstract}
This paper presents a study of seismic damage in low or middle rise steel structures. In order to evaluate the damages of stories and structural members, seismic response analyses about 64 existing steel structures were carried out using 4 seismic waves. From the results of analyses, following conclusions were obtained. 1) The seismic response drift angle of each story can be estimated using base shear coefficient and coefficient of shear distribution at each floor. 2) The damage of columns are slight in case the column-to-beam strength ratio are larger than 1.5. The damage of panel zone increased when the column-to-beam strength ratio are smaller than 1.5 , because the ratio of the yield strength of panel zone to the plastic bending strength on connected members is related very closely to the column-to-beam strength ratio.
\end{abstract}

Keywords: steel structure, seismic response analysis, base shear coefficient, coefficient of shear distribution 鋼構造骨組、地震応答解析、ベースシヤー係数、せん断力分布係数

\section{1. 序}

鋼構造骨組の耐震性能の概略はベースシヤー係数で評価すること ができる。しかし、各層の降伏せん断力の分布や骨組を構成する 柱・梁・接合部パネルそれぞれの部材間耐力比の影響により、建物 の特定層に崩壊機構が形成され当該㕌への損傷が集中し、建物全体 としての耐震性能を十分に発揮できない場合がある。このように、 ベースシヤー係数は建物の第 1 層部分に関する耐力指標であるた め、特定層の損傷集中を考虑した耐震性能までを評価することが難 しい面がある。

建物の地震時の損傷集中について、秋山は、建物の実際の降伏せ ん断力分布の最適な降伏せん断力分布からの隔たりにより損傷分布 則を定量化した1)。この分布則によれば、任意の層の損傷は降伏せ ん断力の分布により推定され、さらにその損傷は当該層の崩壊機構 により変化するとしている。具体的には、当該層の崩壊機構が、柱 の塑性化が梁に先行する柱崩壊機構となる場合、損傷が促進される ことを示している。

また、中島らは、損傷集中を防ぐために必要な骨組の崩壊機構と して梁の塑性化が柱に先行する梁崩壊機構を取りあげ、梁崩壊機構 を確保するために必要な柱梁耐力比について、魚骨形骨組を用いた

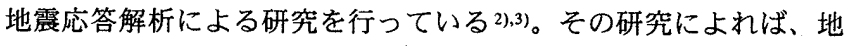

震波の入カレベルの増加にともない梁崩壊機構形成に必要な柱梁耐 力比が増加すること、入力地震波の最大速度が 50kine の場合、柱 梁耐力比が 1.1 程度以上あれば各層の層間変形角の最大応答值の高 さ方向の分布や梁の塑性変形応答は柱が塑性化しない建物と比較し て大差なく、柱の塑性化がほとんど起きないことが示されている。

一方、鋼構造骨組は、各部材の塑性変形により地震エネルギーを 吸収することから、耐震性能を評価するためには各部材に生じる塑 性変形を把握しておく必要がある。長谷川は、柱梁耐力比・パネル 降伏比・ベースシヤー係数をパラメータとした骨組の地震応答解析 をおこない、その結果を用いて、柱梁耐力比・パネル降伏比とべー スシヤー係数から直接骨組の各部材の損傷を予測する手法を提案し た4)。小川、加村、井上らは、任意の床レベルの節点を一つの節点 に集約することで柱梁耐力比・パネル降伏比や降伏せん断力・剛性 の高さ方向の分布などの情報が反映可能で汎用性のある簡便なモテ ルとして魚骨形骨組を提案し、モデル骨組とその骨組を置換した魚 骨形骨組の応答解析結果の比較から、魚骨形骨組を用いた応答解析 による各部材の損傷や崩壊型などの特性の再現性を確認している5)。

以上のような研究を総括すると、鋼構造骨組の損傷集中を考慮し た耐震性能は、ベースシヤー係数により概略的に示された耐震性能 に、降伏せん断力の分布・柱梁耐力比・パネル降伏比の影響を考慮

本論の一部は, 日本建築学会大会学術講演梗概集 (2001年 9 月)に発表している。

*1 宇都宮大学大学院工学研究科 大学院生. 工修

*2 宇都宮大学工学部建設学科 助教授・博士 (工学)

*3 宇都宮大学工学部建設学科 教授・工博

Graduate Student, Graduate School of Eng., Utsunomiya Univ., M. Eng.

Assoc. Prof., Dept. of Architecture and Civil Eng., Faculty of Eng., Utsunomiya Univ., Dr. Eng.

Prof., Dept. of Architecture and Civil Eng., Faculty of Eng., Utsunomiya Univ., Dr. Eng. 
することで評価できると推測される。実在する建物の場合、降伏せ ん断力の分布・柱梁耐力比・パネル降伏比は骨組内で一様な分布を 示すことはほとんどなく、これらを総合的に考慮した鋼構造建物の 地震時の応答性状について言及している研究は少ない。

そこで、本研究では、様々な設計者が設計した多数の実際に建設 された $3 \sim 6$ 層の純ラーメン鋼構造骨組の部材データを用いて応答 解析を行い、地震応答時の骨組の各層間の損傷分布や各部材の損傷 の程度の実状を把握するとともに、ベースシヤー係数・降伏せん断 力の分布・柱梁耐力比・パネル降伏比などの構造特性值と中低層鋼 構造骨組の損傷との関連性を見いだし、構造特性值が中低層鋼構造 骨組の耐震性能にどのような影響を与えるのか検討することを目的 とする。

\section{2. 解析方法}

\section{1 解析骨組}

解析対象骨組は、実在する $3 \sim 6$ 層の純ラーメン構造の重層鋼構 造建物である6),7)。件数は、 3 層 36 件、 4 層 10 件、5 層 10 件、 6 層 8 件の計 64 件である。各建物より、長辺方向の代表的な構面(解 析骨組のほとんどが 2 ～ 析を行った。柱・梁部材の鋼種はすべて $400 \mathrm{~N} / \mathrm{mm}^{2}$ 級鋼材であった。

解析骨組の柱・梁部材の曲げモーメント - 回転角関係および接合 部パネルのせん断力 - せん断変形関倸は、軸力による影響を考慮で きる移動硬化型のbi-liner 型を用いており、降伏応力度を公称值 $235 \mathrm{~N} / \mathrm{mm}^{2}$ 、是硬化係数は柱・梁部材で $2 \%$ 、接合部パネルで $1 \%{ }^{8}$ としている。また、最下層柱脚部は固定とした。

解析骨組の積載荷重は、一率事務所用荷重9を用いた。粘性減衰 は剛性比例型とし、1 次の減衰定数を 0.02 とした。解析プログラ ムには、 p $\Delta$ 効果を考慮できる “club.f” 10)を用いた。

\section{2 入力地震波}

応答解析には、El Centro 波 (NS 成分) · Hachinohe 波 (EW 成分) • Taft 波（EW 成分）と El Centro 波（NS 成分）より抽出した位相を 用い bi-liner 型のエネルギースペクトルに適合するように作成した 人工地震波 wv_elns 波 ${ }^{11)} 4$ 波を用いた。各地震波の最大加速度は、 各骨組への入カレベルを同等にするため、解析骨組の応答解析を繰 り返し、損傷に寄与する地震入力エネルギー $E_{d m}$ の速度換算值が 150kineになるように設定した1)。

\section{3. 解析骨組の概要}

\section{1 部材間䞂力比}

解析骨組のパネル降伏比 $R_{p p}$ と柱梁耐力比 $R_{\mathrm{c}}$ について述べる。各 接合部毎にみた場合、中柱と側柱で当該接合部に接続する部材数が 違う（中柱に属する接合部は、柱、梁それぞれ 2 本ずつに対し、側 柱に属する接合部では柱 2 本に対(梁 1 本)。このことから、中柱 に属する接合部と側柱に属する接合部に分けて $R_{p p}$ と $R_{\mathrm{c}}$ の関係を図 1 に示す。 $R_{p p}, R_{c}$ は、(1),(2) 式よる。

$$
\begin{gathered}
R_{p p}=\sum_{P} M_{y} / \min \left(\sum_{c} M_{p}, \sum_{B} M_{p}\right) \\
R_{c}=\sum_{c} M_{p} / \sum_{B} M_{p} \\
{ }_{P} M_{y}: \text { パネル降伏モーメント } \\
{ }_{c} M_{p}: \text { 各柱の全塑性モーメント } \\
{ }_{B} M_{p}: \text { 各梁の全塑性モーメント }
\end{gathered}
$$

なお、ここで用いた ${ }_{p} M_{y} \cdot{ }_{C} M_{p} \cdot{ }_{B} M_{p}$ は軸力による影響を考慮した ものではない。

$R_{c}$ は主に、側柱で $0.7 \sim 5$ 程度、中柱で $0.5 \sim 2.5$ 程度に分布し ており、 $R_{p p}$ は主に、側柱で $0.6 \sim 2.5$ 程度、中柱で $0.5 \sim 1.5$ 程度 に分布している。

$R_{p p}$ と $R_{c}$ の関係を見ると、 $R_{c}>1.0$ の範囲で $R_{c}$ の增加に伴い $R_{p p}$ も 増加する傾向が見られる。これは、各接合部の接合部パネルの断面 は当該接合部に接続する柱部材の断面と同等のものを使用している ことが関係していると考えられる。

また、建物層数や地震の入力レベルにより変化するが、柱部材へ の損傷をなくすためには、入力地震波の最大速度が 50kine におい ては、 $R_{c}$ が 1.5 以上必要であるとの結果が示されている2)。しかし、 解析対象の実在骨組では、中柱において $R_{\mathrm{r}}<1.5$ となる接合部のほ とんどが $R_{p p}<1.0$ となっていることから、 $R_{c}$ が 1.5 以下の場合、柱 部材の損傷より接合部パネルの損傷が先行し、柱部材の損傷が軽減 されることが推測される。

\section{2 降伏せん断力係数}

解析骨組の降伏せん断力係数について述べる。降伏せん断力係数 $\alpha_{i}$ の定義は(3) 式による。また、第 1 層の降伏せん断力係数を特に ベースシヤー係数と定義する。

$$
\begin{aligned}
& \alpha_{i}=Q_{y i} / W_{i} \\
& W_{i}: i \text { 層の負担する建物重量 } \\
& Q_{y i}: i \text { 層の降伏せん断力 }
\end{aligned}
$$

なお、降伏せん断力の算出方法は数種類あり、それぞれの算出方 法により異なる值を示すが、本研究では、各解析骨組の降伏せん断 力を外力分布に左右されずに算出することができる節点モ一メント 分割法 ${ }^{22}$ により算出した。

解析骨組のベースシヤー係数 $\alpha$, 頻度分布を図 2 に示す。解析 骨組のベースシヤー係数は、約 $80 \%$ の骨組で $0.2 \sim 0.4$ の間に分布 しているが、約 $20 \%$ の骨組で 0.4 以上と数値が高いの骨組も見受け られる。

解析骨組の損傷分布指標 $p_{i}$ について検討する。 $p_{i}$ は (4) 式により 定義される。ここで $A_{i}$ は通常の耐震設計で用いられる地震層せん 断力係数の高さ方向の分布を示す值である。但し、 $A_{i}$ の算定には、 固有周期の精算値を用いている。

$$
p_{i}=\frac{\alpha_{i}}{\alpha_{1} \cdot A_{i}}
$$

$p_{i}$ は、骨組の降伏せん断力係数分布 $\alpha_{i} / \alpha_{1}$ と地震時に生じるせん断 力係数分布 $A_{i}$ との隔たりを示す值であり、当該層への損傷集中を 表す指標の一つとなる値である1)。 $p_{i}$ の高さ方向の分布を図 3 に示 す。縦軸は当該階数 $(i)$ をその建物階数 $(N)$ で除した値である。

ほとんどの解析骨組で、降伏せん断力係数の分布は中間層で $A_{i}$ 分布より小さく、最上層で大きくなっていることが判る。節点モ一 メント分割法では、最上層及び最下層でせん断力を過大評価する性 質があることも要因の一つである。

\section{3 一次固有周期}

固有值解析により、解析骨組の一次固有周期を算出した。この一 次固有周期 $T$ とベースシヤー係数 $\alpha_{1}$ との関係を図 4 に示す。

一次固有周期は、0.5 1.5 秒程度であった。一次固有周期とベー スシヤー係数の関係を見ると、反比例的な関係がある。この反比例 
的な関係は、骨組の階数により多少の差が見られる。

\section{4. 解析結果及び考察}

\section{1 層間変形角}

層間変形角を層間の損傷と定義し、損傷分布と層せん断力係数分 布の関係および損傷の程度について検討を加える。

\section{1 .1 第 1 扈の層間変形角}

損傷分布を求めるためには基準となる数値を決定する必要があ る。本論文では、第 1 層を層間変形角の基準值として以降の考察を 進めることとする。ここでは、基準値である第 1 層の層間変形角と 建物の基本となる耐力指標であるべースシヤー係数の関係について 検討する。

応答解析により得られた 1 層の層間変形角の最大応答値 ${ }_{d y} R_{1}$ と ベースシヤー係数 $\alpha_{1}$ との関係を入力地震波別に図 5 に示す。

${ }_{d y} R_{1}$ と $\alpha_{1}$ との関係は反比例的な関係にある。また、四中に(5) 式 による関係を実線で示した。(5) 式とそれぞれのデー夕との関係か ら、層間変形角の最大応答值の上限と $\alpha_{1}$ の関係を概ね $(5)$ 式で評価 できると考えられる。

$$
{ }_{d y} R_{1}=\frac{1}{150 \cdot \alpha_{1}}
$$

\subsection{2 層間変形角の分布}

地震応答解析により得られた各層の層間変形角の最大応答値の高 さ方向の分布を損傷分布として、この損傷分布ついて検討する。

解析骨組の各層の層間変形角最大応答值 ${ }_{d y} R_{i}$ を当該骨組の第 1 層 の層間変形角最大応答值 ${ }_{d y} R_{1}$ で除した值を損傷分布係数 ${ }_{d y} R_{i} /{ }_{d y} R_{1}$ 之 して損傷分布指標 $p_{i}$ との関倸を図 6 に示す。

各層の損傷分布係数は、 $p_{i}$ とほぼ反比例の関係を示している。特 に、周期によるエネルギー入力の変動がほとんどない人工地震波 wv_elns 波を入力した場合、ほほ(6) 式で近似されると推定できる。

$$
\frac{{ }_{d y} R_{i}}{{ }_{d y} R_{i}}=\frac{1}{p_{i}}
$$

そこで、この近似値を損傷分布係数の基準值として、この基準值
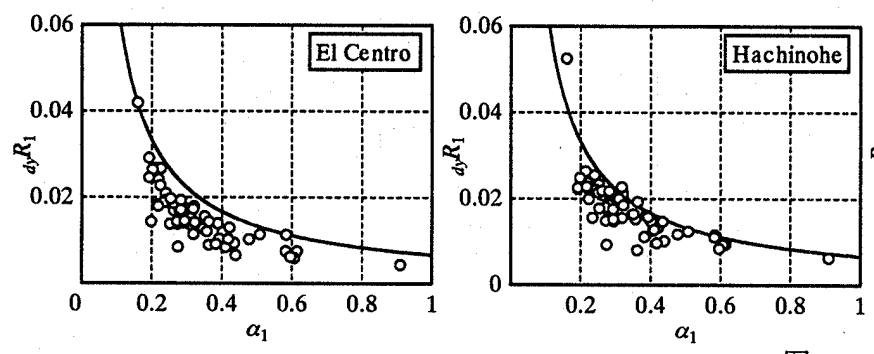

$1 / p_{i}$ と損傷分布係数 ${ }_{d y} R_{i} / d y R_{1}$ との隔たりについて検討する。

入力地震波別に見ると、Hachinohe 波、wv_elns 波を入力した場 合の ${ }_{d y} R_{i} / d y R_{1}$ は基準値に近い値を示している。一方、El Centro 波で は、前記の 2 波に比べ基準值からの隔たりが大きい骨組がかなり見 受けられ、Taft 波ではより大きな隔たりの層が多くなっている。こ の場合、さらに、最上層における ${ }_{d y} R_{i} /{ }_{d y} R_{1}$ は基準值の 2 倍程度と他 の 3 波に比べ、特に大きくなっている。この原因として、動的応答
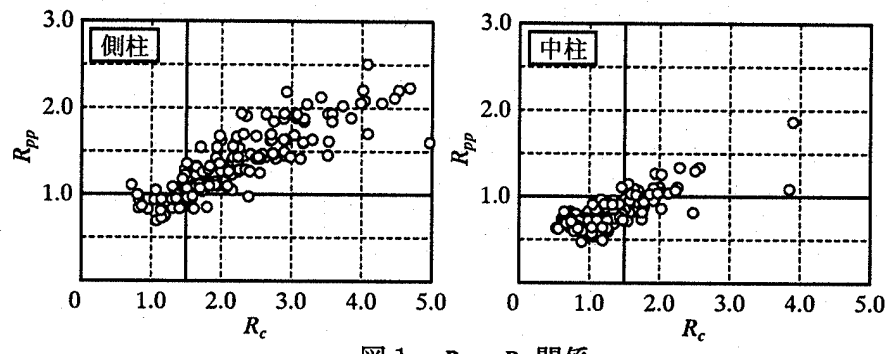

図 $1 R_{p p}-R_{c}$ 関係

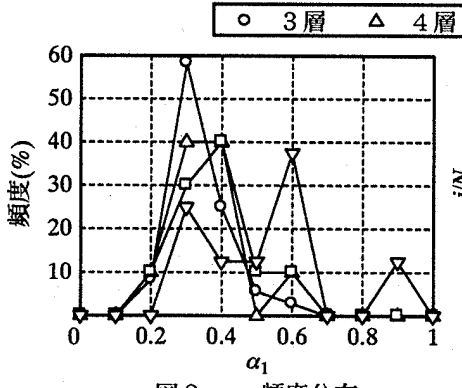

図 $2 \quad \alpha_{1}$ 影度分布

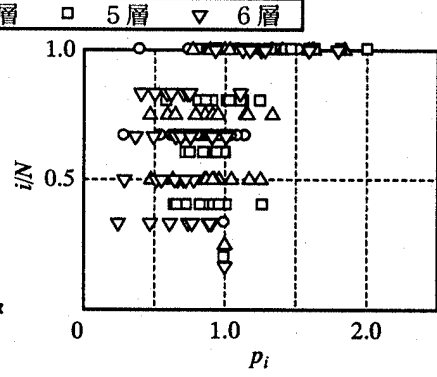

図3 $p_{i}$ 分布

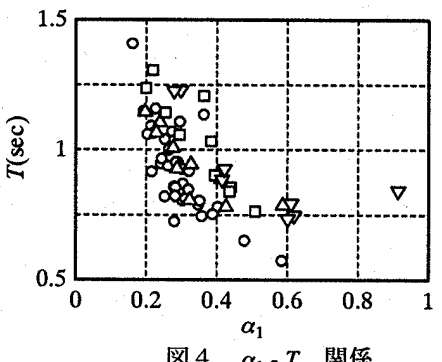

図 $4 \quad \alpha_{1}-T$ 関俰
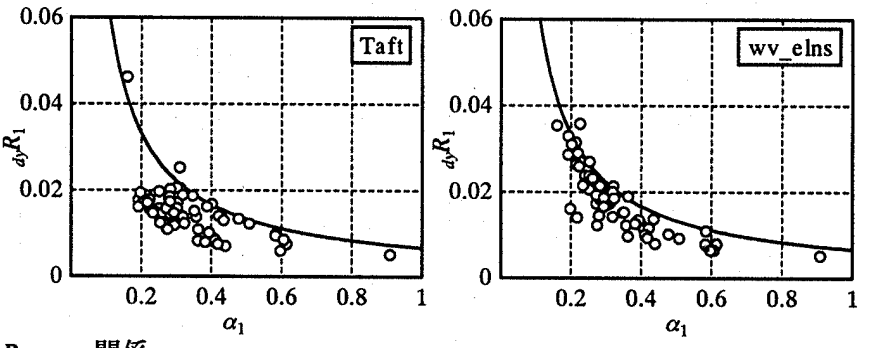
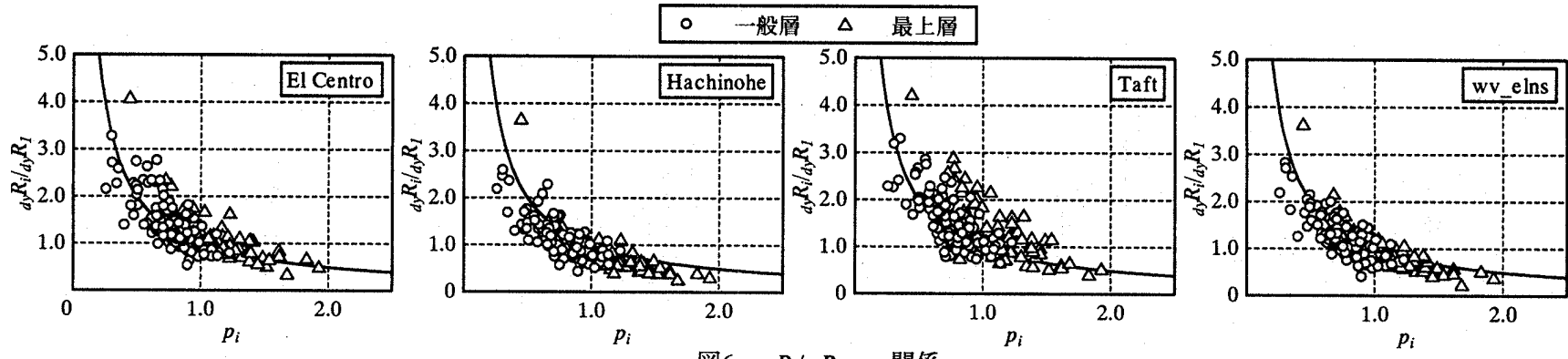

図6 ${ }_{d y} R_{i} / d y R_{1}-p_{i}$ 関倸 
時の各層に生じるせん断力の分布が、せん断力係数分布 $A_{i}$ からか け離れていることが考えられる。

そこで、各層の層せん断力の最大応答值 ${ }_{d y} Q_{i}$ を当該骨組の 1 層の 層せん断力の最大応答值 ${ }_{d y} Q_{1}$ で除した值を地震入力時のせん断力係 数分布 ${ }_{d y} A_{i}$ として ${ }_{d y} A_{i}$ と $A_{i}$ の関係をみることとし、これらの比 ${ }_{d y} A_{i} /$ $A_{i}$ の高さ方向の分布を地震波別に図 7 に示した。

図 7 に示すように、 ${ }_{d y} A_{i} / A_{i}$ は、Hachinohe 波及びwv_elns 波では $0.7 \sim 1.2$ 程度であるが、El Centro 波及びTaft 波では $0.8 \sim 1.6$ 程 度と上層部に生じるせん断力が Hachinohe 波及びwv_elns 波に比べ 大きくなっていることが分かる。

\section{1 .3 啗の損傷指標}

前項までの層間変形角の応答性状に関する検討から、1 層の層間 変形角の最大応答值とベースシヤー係数の関係については (5) 式、 層間変形角の分布と損傷分布指標の関係については入力地震波によ りばらつきがあるが(6) 式で大略表すことができることを示した。 この 2 式より、(7) 式の関倸式が得られる。

$$
{ }_{d y} R_{i}=\frac{1}{150} \cdot \frac{1}{{ }_{d y} \alpha_{i}}
$$

ここで、 ${ }_{d y} \alpha_{i}$ の定義は (8) 式による。

$$
{ }_{d y} \alpha_{i}=\frac{\alpha_{i}}{A_{i}}
$$

${ }_{d y} \alpha_{i}$ は、 $i$ 層の降伏せん断力係数 $\alpha_{i}$ を $i$ 層のせん断力係数分布 $A_{i}$ で 除した值であり、降伏せん断力係数分布が $A_{i}$ と等しく $i$ 層の降伏せ ん断力係数が $\alpha_{i}$ となると仮定した骨組の 1 層の降伏せん断力係数に 対応する值である。 $i$ 層の降伏せん断力係数 $\alpha_{i}$ を 1 層の降伏せん断 力係数に換算する理由は、 $\alpha_{i}$ により示される性能は高さ方向の地震 時のせん断力の增分 $A_{i}$ により変化することから、他の層と比較す るため高さ方向の影響を考虑した值とする必要があるためである。 ここで、 ${ }_{d y} \alpha_{i}$ をべースシヤー係数換算值と呼ぶこととする。

このことから、(7)式は、ベースシヤー係数換算值 ${ }_{d y} \alpha_{i}$ により、各 層の層間変形角の最大応答値を推定できることを示している。 ${ }_{d y} \alpha_{i}$ と各層の層間変形角最大応答值の関係を図 8 に示す。ほぼ、
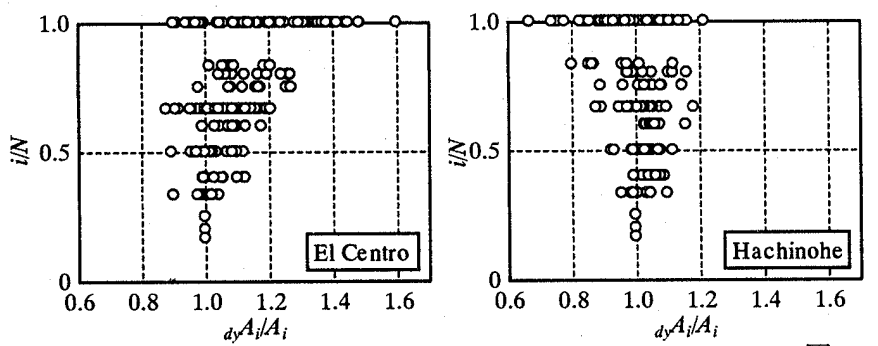

(7) 式により層間変形角の最大応答値の上限值を評価できることが 分かる。また、ベースシヤー倸数換算値が ${ }_{d y} \alpha_{i}>0.3$ となる層では、本 解析の入カレベルでは、層間変形角の最大応答值がおよそ $1 / 50$ $(0.02 \mathrm{rad})$ 以下になっていることが分かる。

\section{2 各部材の損傷}

各部材の損傷について検討する。損傷は累積塑性変形倍率 $\eta$ によ り評価する。累積塑性変形倍率は(9) 式による。

$$
\eta=W /\left(M_{p} \cdot \theta_{p}\right)
$$

$W$ : 各部材の曲げ変形による履歴吸収エネルギーの総和

$M_{p}:$ 部材の全塑性モーメント(接合部パネルでは $M_{\mathrm{y}}$ )

$\theta_{p}: M_{p}$ に対応する部材端部の回転角 (接合部パネルでは $\theta_{y}$ )

各接合部ごとに接合部パネル・柱・梁各部材の累積塑性変形倍率 $\eta_{p} \cdot \eta_{c} \cdot \eta_{b}$ (柱については上下、梁部材については左右の部材のうち 大きい值）と当該層の層間変形角 ${ }_{d y} R_{i}$ の関係について検討する。な お、各接合部には、上下層それぞれに層間変形角が得られるが、梁・ 接合部パネルについての検討では上下層の層間変形角の平均値、柱 部材については対応する層の層間変形角を当該層の層間変形角 ${ }_{d y} R_{i}$ としている。

最下層柱脚部および最上層柱頭部の接合部を除く骨組の全接合部 のうち、中柱に属する接合部について、接合部パネルの $\eta_{p}$ と ${ }_{d y} R_{i}$ と の関係を図 9、柱部材の $\eta_{c}$ と ${ }_{d y} R_{i}$ との関倸を図 $10 、$ 梁部材の $\eta_{b}$ と $_{d y} R_{i}$ との関係を図 11、側柱について、接合部パネルの $\eta_{p}$ と ${ }_{d y} R_{i}$ との関 係を図 12 、柱部材の $\eta_{c}$ と ${ }_{d y} R_{i}$ との関係を図 13 、梁部材の $\eta_{b}$ と ${ }_{d y} R_{i}$ と の関係を図 14 に示す。また、接合部パネルは $R_{p p}$ 、柱及び梁部材は $R_{\mathrm{c}}$ により分類して示している。

中柱に属する接合部について検討する。

接合部パネルは、 $R_{p p}<0.8$ となる接合部において損傷が激しく、首 間変形角 $1 / 50(0.02 \mathrm{rad})$ 程度で $\eta_{p}$ が最大で約 35 程度となっている。 また、 $R_{p p}>1.0$ では、接合部パネルの損傷は $\eta_{p}<7$ とかなり小さくなつ ている。

柱部材では、図 10-a、図 10-b より $R_{c}<1.5$ の接合部において、層 間変形角が $1 / 40 （ 0.025 \mathrm{rad）}$ 以上では、損傷の最大值は $\eta_{c}=7$ 程度と
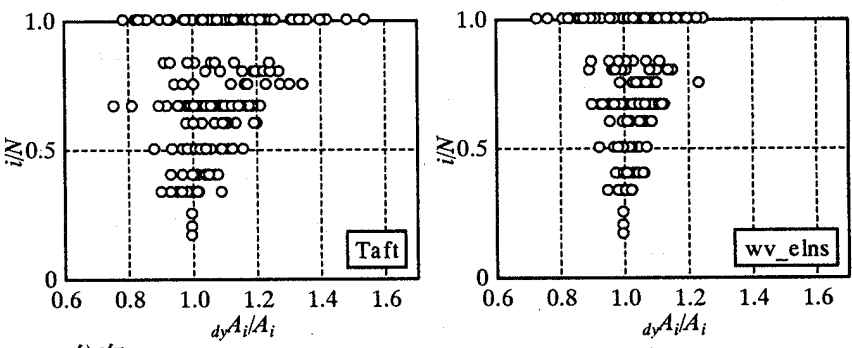

図7 ${ }_{d y} A_{i} / A_{i}$ 分布

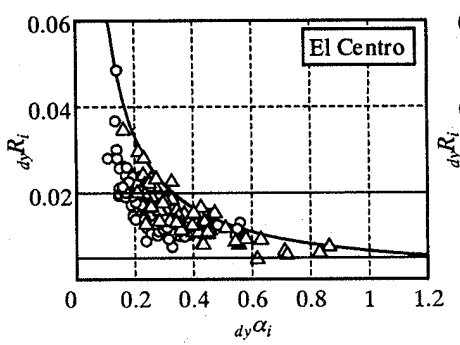

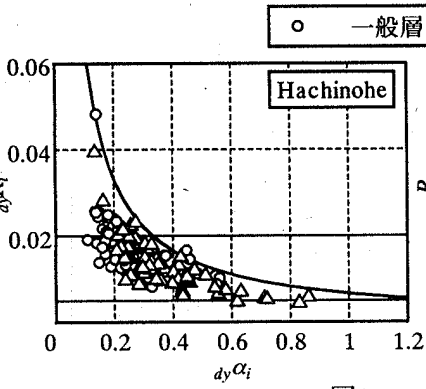

図8

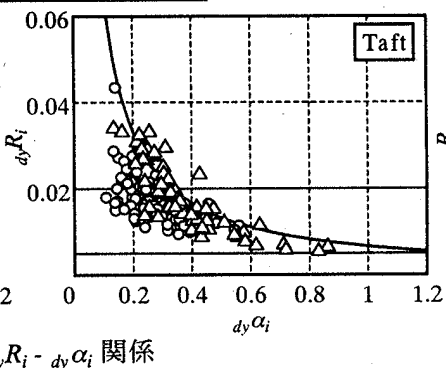

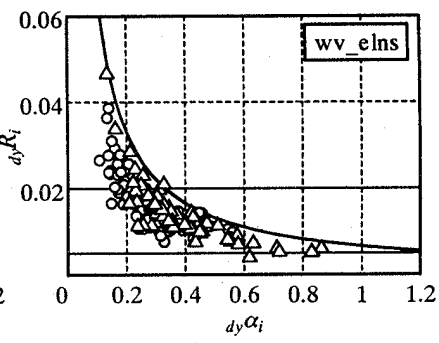



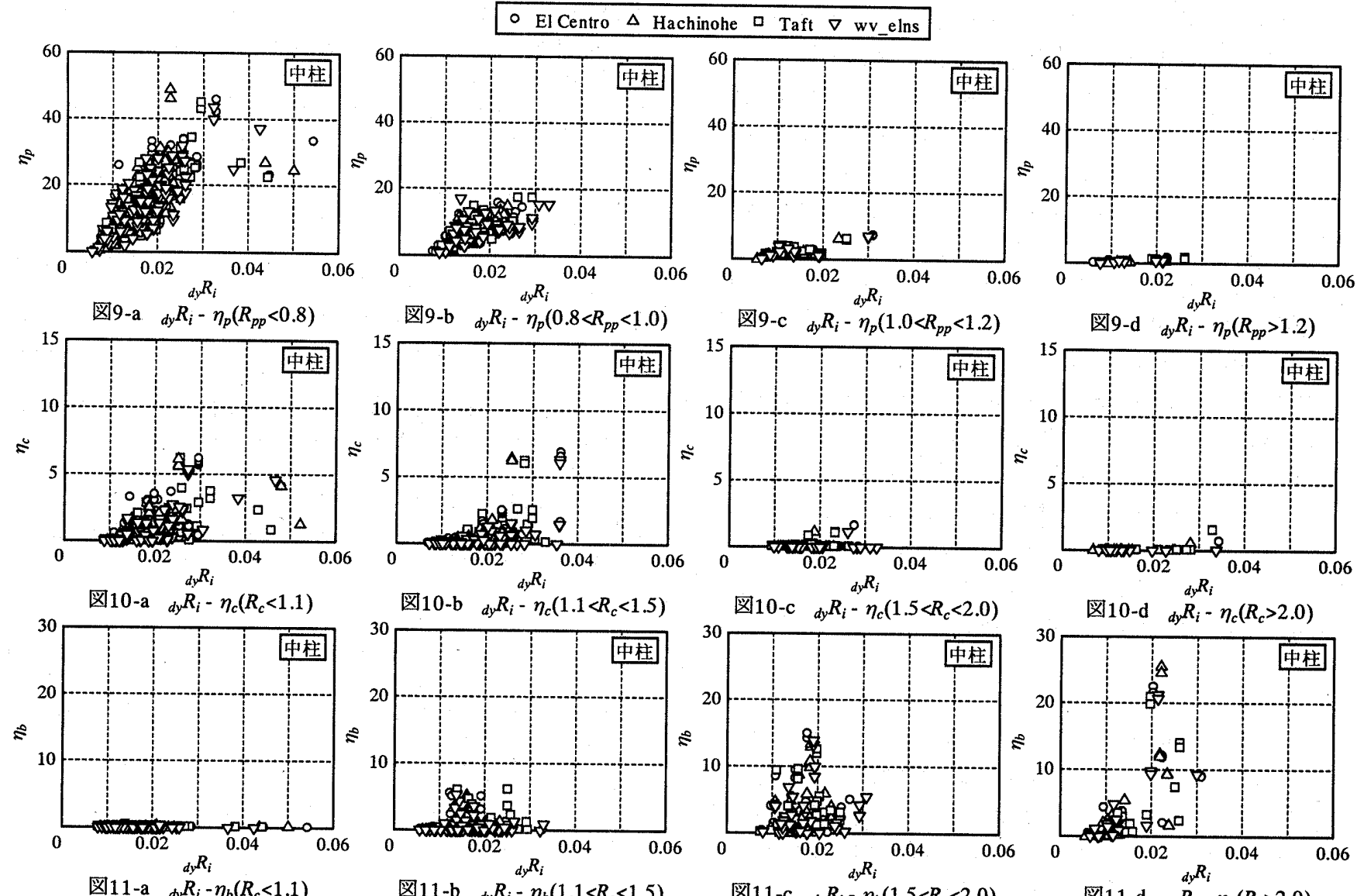

図10-d ${ }_{d y} R_{i}-\eta_{c}\left(R_{c}>2.0\right)$

図11-a ${ }_{d y} R_{i}-\eta_{b}\left(R_{c}<1.1\right)$

図11-b ${ }_{d y} R_{i}{ }^{d y} \eta_{i} \eta_{b}\left(1.1<R_{c}<1.5\right)$

図11-c ${ }_{d y} R_{i}-\eta_{b}\left(1.5<R_{c}<2.0\right)$

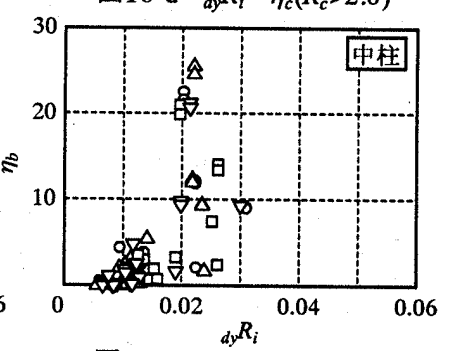

図11-d ${ }_{d y} R_{i}-\eta_{b}\left(R_{c}>2.0\right)$
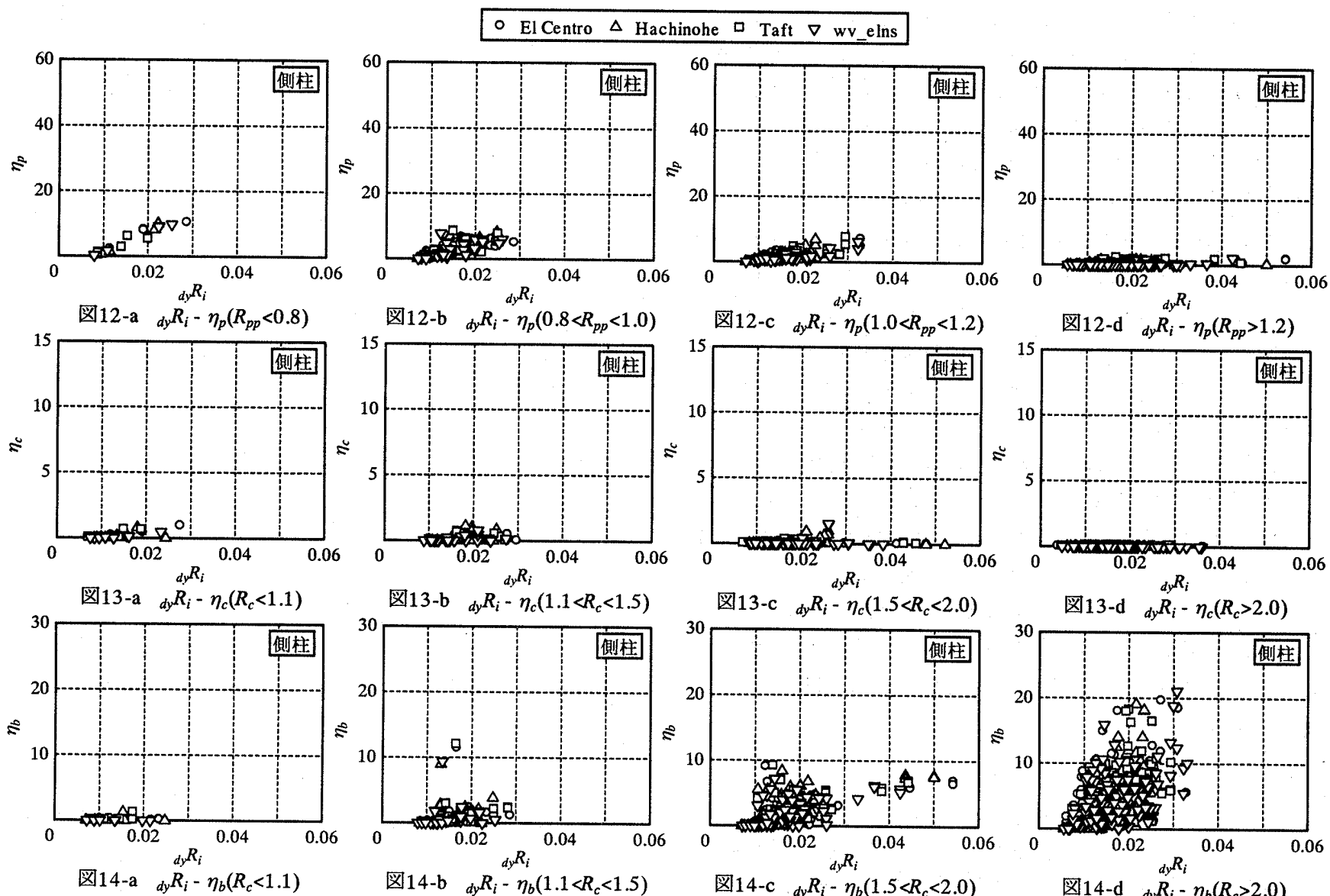

図14-a ${ }_{d y} R_{i}-\eta_{b}\left(R_{c}<1.1\right)$

図14-c ${ }_{d y} R_{i}-\eta_{b}\left(1.5<R_{c}<2.0\right)$

図14-d ${ }_{d y} R_{i}-\eta_{b}\left(R_{c}>2.0\right)$ 
なっている。このことから、 $R_{c}<1.1$ と $1.1<R_{c}<1.5$ では、層間変形角 と柱の損傷の傾向はほぼ等しくなる可能性が推測される。このよう に、 $R_{c}<1.5$ では、柱の損傷の最大值と層間変形角の関係の傾向が変 わらないのは、図 1 の中柱の $R_{c}$ と $R_{p p}$ の関係から判るように、 $R_{c}<1.5$ となる接合部のほとんどが $R_{p p}<1.0$ となり、図 9-a,b から明らかなよ うに接合部パネルでの損傷が増加することにより、柱への損傷の負 担が軽減しているためと考えられる。

梁部材では、 $R_{c}<1.1$ では全く損傷はなく、 $1.1<R_{c}<1.5$ でも最大で $\eta_{b}=5$ 程度と僅かな損傷である。

次に、側柱に属する接合部について検討する。

側柱に属する接合部では、接合部パネル・柱・梁の各部材とも、 中柱に属する接合部より小さな損賃に留まっている。

接合部パネルで $\eta_{p}=10$ 程度以下、柱部材で $\eta_{c}=5$ 程度以下の損傷を 示し、 $R_{p p} \cdot R_{c}$ による違いはあまり認められない。梁部材では、中 柱と同様に $R_{c}$ が大きい接合部ほど大きな損傷を示す傾向にあり、 かつ、損楊を生じる部材も多いことが認められる。このことより、 側柱に属する接合部は、梁に損傷が集中しやすいことが分かる。

\section{5. まとめ}

中低層鋼構造骨組の大地震時における動的応答性状の実状を把握 し、さらにベースシヤー係数・降伏せん断力係数・柱梁耐力比・パ ネル降伏比などの構造特性值が骨組の応答性状に与える影響を把握 するために、実在する $3 \sim 6$ 層の中低層鋼構造建物の骨組デー夕 64 件を用いて、動的応答解析を行い、層の損傷及び部材の損傷につい て検討を行った。その結果、実在する中低層鋼構造骨組について、 地震時の層間変形角の応答值と降伏せん断力係数 $\alpha_{i}$ や地震応答時 のせん断力係数分布 $A_{i}$ との関連性があることを示し、その関係式 を導くことができた。また、柱・梁・接合部パネルの各部材の損傷 と層間変形角の応答值との関係がパネル降伏比及び柱梁耐力比の影 響をどのように受けるかについても検討した。

それらの結果を要約すると以下のようになる。

1) 層間変形角の応答值と降伏せん断力係数との関係について考察 した結果、せん断力係数分布 $A_{i}$ を考慮したベースシヤー係数換算 値 ${ }_{d y} \alpha_{i}$ と層間変形角応答值の上限値の相関関係を示すことができ た。このことより、中低層骨組の層の損傷は、降伏せん断力係数と 降伏せん断力分布の影響が支配的であり、(7) 式で層間変形角の最 大応答値の上限值が推定されることが確認された。

2）部材の損傷について検討した結果、側柱では梁以外の部材はほ とんど損傷を受けていないこと、中柱では、柱梁耐力比が 1.5 以上 であれば柱に損傷がほとんど生じないことが確認された。また、通 常、接合部パネルは柱部材と同様の断面を用いることから、柱梁耐 力比が 1.5 以下となると、パネル降伏比が 1 以下となる接合部が多 く、柱梁酎力比が減少しても接合部パネルの損傷負担が増加し、結 果として、柱梁耐力比が 1 以下であっても柱の損傷はあまり増加し ないことが推測される。

\section{参考文献}

1)、秋山宏：エネルギーの釣合に基づく建築物の耐震設計，技報堂出版，1999.

2）中島正愛, 澤泉紳一: 鉄骨骨組の地震応答に及ぽす柱梁耐力比の影響(その 1 : 梁崩壊機構を形成するために必要な柱梁耐力比), 銿構造論文集, 第 6 巻 第23号, pp.117-132，1999.9.
3) 澤泉紳一, 中島正愛:鉄骨骨組の地霞応答に及ぼす柱梁耐力比の影響 (その 2 :柱の塑性化を許す鉄骨骨組の地震応答)，銅構造論文集, 第 6 巻第23号, pp.133-148, 1999.9.

4) 長谷川隆:地震時における鉄骨構造骨組の柱, 梁, 接合部パネルの損傷予測, 日本建築学会技術報告集，第 10 号，pp.105-110，2000.6.

5）小川厚治, 加村久哉, 井上一朗: 銅構造ラーメン骨組の魚骨形地震応答解析 モデル，日本建筑学会構造系論文集，第 521 号，pp.119-126，1999.7.

6) 增田浩志, 田中㳯夫, 秋田智, 前田憲太郎: 中低層鋼構造骨組の耐震性能 その 1 調查骨組の概要と構造部材, 鎆構造論文集, 第 5 巻第 19 号, pp.65$72,1998.9$

7) 前田憲太郎, 增田浩志, 秋田智, 田中淳夫: 中低層銅構造骨組の耐震性能 その 2 調查建物の耐震性能, 銅構造論文集, 第 7 巻第 25 号, pp.43-52, 2000.3 .

8) 建設省建築研究所一銅材俱楽部 而挴性能共同研究: 数值解析研究会報告書 ～地震纫答解析による角形銅管柱・H形鍓梁ラーメン構造部材の望性変形応 答の評価〜, 1995.7.

9) 日本建築学会 : 建築物荷重指針・同解説, 1993.

10）小川厚治, 多田元英:柱・梁接合部パネルの変形を考慮した静的・動的応答 解析プログラムの開発, 第17回情報システム利用技術シンポジウム, pp.7984, 1994.12

11) Yihua Huang, Akira Wada, Hiroki Kawai and Mamoru Iwata:Study of Damage Tolerant Structure (Part 4) Response Analysis of Bending Shear Pole Model, 日本 建築学会大会学術講演梗概集 C 構造 II ,pp.1513-1514,1993.9.

12) 日本建築学会: 建物耐震設計における保有水平耐力之耐震性能(1990), 丸善, 1990 .

（2002年 1 月 10 日原稿受理，2002年 5 月 28 日採用決定） 